\title{
FDX2 and ISCU Gene Variations Lead to Rhabdomyolysis With Distinct Severity and Iron Regulation
}

Sebastian Montealegre, PhD, Elise Lebigot, MD, PhD, Hugo Debruge, BSc, Norma Romero, MD, PhD, Bénédicte Héron, MD, Pauline Gaignard, MD, PhD, Antoine Legendre, MD, PhD, Apolline Imbard, MD, PhD, Stéphanie Gobin, PhD, Emmanuelle Lacène, BSc, Patrick Nusbaum, PhD, Arnaud Hubas, PhD, Isabelle Desguerre, MD, PhD, Aude Servais, MD, PhD, Pascal Laforêt, MD, PhD, Peter van Endert, MD, PhD, François Jérome Authier, MD, PhD, Cyril Gitiaux, MD, PhD, and Pascale de Lonlay, MD, PhD

Neurol Genet 2022;8:e648. doi:10.1212/NXG.0000000000000648

\section{Abstract}

\section{Background and Objectives}

To determine common clinical and biological traits in 2 individuals with variants in ISCU and FDX2, displaying severe and recurrent rhabdomyolyses and lactic acidosis.

\section{Methods}

We performed a clinical characterization of 2 distinct individuals with biallelic ISCU or FDX2 variants from 2 separate families and a biological characterization with muscle and cells from those patients.

\section{Results}

The individual with FDX2 variants was clinically more affected than the individual with ISCU variants. Affected FDX2 individual fibroblasts and myoblasts showed reduced oxygen consumption rates and mitochondrial complex I and PDHc activities, associated with high levels of blood FGF21. ISCU individual fibroblasts showed no oxidative phosphorylation deficiency and moderate increase of blood FGF21 levels relative to controls. The severity of the FDX2 individual was not due to dysfunctional autophagy. Iron was excessively accumulated in ISCUdeficient skeletal muscle, which was accompanied by a downregulation of IRP1 and mitoferrin2 genes and an upregulation of frataxin $(F X N)$ gene expression. This excessive iron accumulation was absent from FDX2 affected muscle and could not be correlated with variable gene expression in muscle cells.

\section{Discussion}

We conclude that FDX2 and ISCU variants result in a similar muscle phenotype, that differ in severity and skeletal muscle iron accumulation. ISCU and FDX2 are not involved in mitochondrial iron influx contrary to frataxin.
Correspondence

Dr. de Lonlay

pdelonlay@gmail.com

From the Inserm U1151 (S.M., H.D., P.E., P.d.L.), Institut Necker Enfants-Malades, Paris; Reference Center of Inherited Metabolic Diseases (S.M., A.I, A.S., P.d.L.), Necker-EnfantsMalades University Hospital, APHP, Imagine Institute, Paris University, Filière G2M; Biochemistry Laboratory (E. Lebigot, P.G.), Filière G2M, Bicêtre Hospital, APHP Paris Saclay, Le Kremlin Bicêtre; Sorbonne Universié (E. Lacène), UPMC, INSERM UMR974, Center for Research in Myology, Neuromuscular Morphology Unit, Myology Institute, AP-HP, East-Paris Reference Center of Neuromuscular Diseases, GHU Pitié-Salpêtrière; Neurology Unit (N.R., B.H.), Trousseau Hospital, APHP, Filière G2M; M3C-Necker (A.L.), Congenital and Pediatric Cardiology, Hôpital Universitaire Necker-Enfants Malades; Biochemistry Department (A.I.), Necker-Enfants-Malades University Hospital, APHP, Paris University; Genetics Department (S.G.), Necker-Enfants-Malades University Hospital, APHP; Genetics and Molecular Biology (P.N., A.H.), Laboratoire de Culture Cellulaire, Hôpital Cochin, Paris; Reference Center of Neuromuscular Diseases (I.D., C.G.), Necker-Enfants-Malades University Hospital, APHP, Filière Filnemus; Adult Nephrology \& Transplantation (A.S.), Necker-Enfants-Malades University Hospital, APHP, Inserm U1163, Imagine Institute, Paris Descartes University; Department of Neurology (P.L.), Raymond-Poincaré Hospital, Garches, and Inserm U1179 Versailles Saint-Quentin-en-Yvelines University, Montigny-le-Bretonneux; and Reference Center for Neuromuscular Disorders (F.J.A., C.G.), Department de Pathologie, Henri Mondor Hospital, APHP, IMRB U955, Faculty of Medicine, Creteil, France.

Go to Neurology.org/NG for full disclosures. Funding information is provided at the end of the article.

The Article Processing Charge was funded by the authors.

This is an open access article distributed under the terms of the Creative Commons Attribution-NonCommercial-NoDerivatives License 4.0 (CC BY-NC-ND), which permits downloading and sharing the work provided it is properly cited. The work cannot be changed in any way or used commercially without permission from the journal. 


\section{Glossary}

ATP = adenosine triphosphate; $\mathbf{B S A}=$ bovine serum albumin; $\mathbf{C K}=$ creatine kinase EBSS $=$ Earle's balanced salt solution; $\mathbf{F e}-\mathbf{S}$ = iron-sulfur; FRDA = Friedreich ataxia; FXN = frataxin; OXPHOS = oxidative phosphorylation; $\mathbf{R M}$ = rhabdomyolysis; SDH $=$ succinyl dehydrogenase.

Rhabdomyolysis (RM) is an acute injury of skeletal muscle that results from environmental causes or from inherited diseases. ${ }^{1}$ In the latter case, RMs are triggered by a catabolic state such as a febrile illness, fasting, and/or effort. Mitochondrial oxidative phosphorylation (OXPHOS) deficiencies are a rare cause of $\mathrm{RM}$, including variants in mitochondrial DNA or in nuclear genes, ${ }^{2}$ especially ISCU (iron-sulfur [Fe-S ] cluster scaffold homolog, OMIM \#611911) $)^{3-5}$ and FDX2 (OMIM \#614585) $)^{6}$ ensuring OXPHOS electron transfer and lipoic acid synthesis.

Deleterious variants in ISCU and FDX2 perturb the assembly of mitochondrial Fe-S clusters. Contrary to other diseases involving the Fe-S cluster pathway and leading to multisystem abnormalities, ${ }^{7}$ the clinical picture of patients with ISCU or FDX2 variants is mainly limited to skeletal muscle. Patients related with ISCU variants ${ }^{8}$ of northern Swedish descent, ${ }^{3,8-10}$ presented with a myopathy characterized by a progressive muscle weakness, frequent ptosis, RM since childhood, and lactic acidosis, worsened by low-level exercise. ${ }^{8,11,12}$ The clinical phenotype of a reported FDX2 patient is similar to ISCU phenotype. ${ }^{6}$ More recently, FDX2 variants were reported in several patients with optic atrophy and reversible leukoencephalopathy. ${ }^{13}$ Biochemical investigations in cells deficient for either ISCU or FDX2 revealed a distinctive deficiency of several mitochondrial $\mathrm{Fe}-\mathrm{S}$ proteins (complex I, II, and III of the electron transport chain and mitochondrial aconitase) ${ }^{3,4,6,12-17}$ Skeletal muscle histology was normal in the FDX2-deficient patient having RM, whereas iron overload was shown in ISCU-deficient myofibers ${ }^{12}$ and in FDX2deficient muscle fibers from the patients with neurologic presentation. $^{13}$

Here, we report variants in the genes FDX2 and ISCU in 2 distinct individuals who presented with recurrent episodes of severe RM. We compared biological alterations in skeletal muscle and myoblasts of both individuals, a few data of the FDX2 patient being already described. ${ }^{18}$ We investigated autophagy and the expression of genes involved in iron regulation.

\section{Methods}

Informed consent was obtained from both individuals after obtaining the ethics approval to work on human samples by the Comite pour la protection des personnes of the University Paris XI (2016) and the declaration of human myoblasts to the Département de la Recherche Clinique et du Développement. Myoblasts from P1 were obtained from skeletal muscle biopsy from the deltoid region and 3 control individuals from the paravertebral region. Isolation and growth of myoblasts was performed as previously described. ${ }^{19}$ No myoblasts were available for $\mathrm{P} 2$.

\section{Genetic Analysis}

White blood cells from the affected individuals and their parents were used a source of DNA after informed consent. Genomic DNA $(1 \mu \mathrm{g})$ extracted from individual (P1) and his parents was analyzed by whole-exome sequencing as previously reported. ${ }^{20}$ For P2, and to exclude known metabolic and calcic genes involved in RM for P1, a panel of genes dedicated to RM was studied as previously described. ${ }^{19}$ Bioinformatic analysis was configured for identification of qualitative and quantitative variations.

Pathogenic variants in FDX2 and ISCU were confirmed by using the Sanger method with specific primers. The PCR products were sequenced and a BigDye Terminator Cycle Sequencing Ready Reaction Kit (version 3.1; Applied Biosystems, Foster City, CA) and then analyzed with SeqScape software (version 3.0; Applied Biosystems).

\section{Myopathologic Study}

For each patient, $7-\mu \mathrm{m}$ cryostat cross-section from deltoid muscle samples was performed for routine histologic staining (hematoxylin-eosin, oil red, periodic acid-Schiff, Gomori trichrome, succinyl dehydrogenase $[\mathrm{SDH}]$, and cytochrome c oxidase). In addition, Perls staining was used for iron $\left(\mathrm{Fe}^{3+}\right)$ visualization. Automated immunochemistry for regenerating myofibers (CD56/NCAM) (clone \#NCL-CD56-1B6, 1/100; Novocastra, Antony, France) and complement activation (MAC/C5b-9) (clone \#ab55811, 1/50; Dako, Glostrup, Denmark) were performed using Bond-III automaton (Leica, Nanterre, France).

\section{Electron Microscopy}

Samples were fixed in glutaraldehyde (2.5\%, pH 7.4), followed by postfixation in osmium tetroxide $(2 \%)$ and embedded in resin (EMBed-812; Electron Microscopy Sciences, Hatfield, PA). Ultra-thin sections were stained with lead citrate and uranyl acetate, observed using a Philips CM120 electron microscope (Philips, Amsterdam, the Netherlands) and recorded with a Morada camera (Soft Imaging System, Münster, Germany).

\section{Gene Expression Analysis}

Total RNA from skeletal muscle was obtained by TRIzol extraction (Invitrogen, Waltham, MA). Complementary DNA was synthesized from $1 \mu \mathrm{g}$ of total RNA by means of the High Capacity RNA-to-cDNA Kit (Applied Biosystems) after 

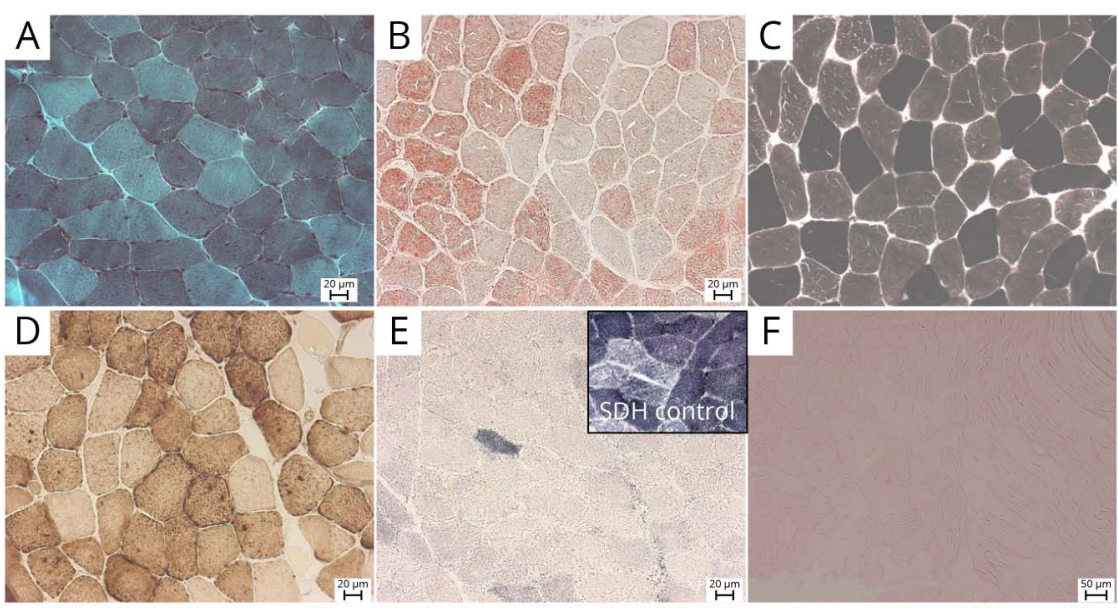

E
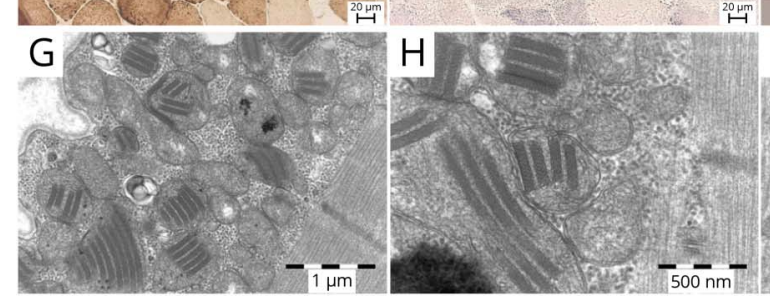
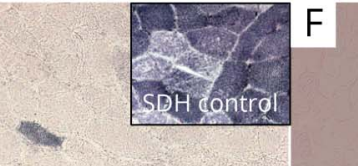

(A-I) Histochemical and electron microscopy analysis of deltoid muscle biopsy. (A) Gomori trichrome staining shows slight mitochondrial (fuchsinophile) subsarcolemma overload. (B) (ORO) important lipid accumulation. (C) (ATP 9.40) predominance of fibers type 1. (D) (COX) absence of COX coloration in a few fibers. (E) (SDH) almost complete absence of SDH enzyme activity in muscle fibers, control SDH section in the up corner. (F) No iron deposit was noted in Perls coloration. (G-I) Ultrastructural study shows the presence of abnormal mitochondria containing palisade crystals, proliferation of mitochondrial crests with osmiophilic inclusions in some mitochondria, and numerous lipid droplets. ATP = adenosine triphosphate; COX = cytochrome c oxidase; SDH = succinyl dehydrogenase.

depleting genomic DNA. The expression of IRP1, mitoferrin2, and frataxin $(F X N)$ genes in skeletal muscle was assessed by quantitative reverse transcription PCR using Power SYBR Green PCR Master Mix, using $\beta$-actin as a housekeeping gene. The RQ value was equal to $2 \Delta \Delta \mathrm{ct}$ where $\Delta \Delta$ ct is calculated by (Ct target $-\mathrm{Ct} \beta$-actin) test sample - (Ct target - Ct $\beta$-actin $)$ calibrator sample. Each value was derived from 3 technical replicates. The probes were as follows: FXN: Fw: 5'-ccttgcagacaagccataca-3', Rv: 5'-ccactggatggagaagatag- $3^{\prime 21}$; IRP1: Fw: $5^{\prime}$-tgcttcctcaggtgattggctaca-3', Rv: $5^{\prime}$-tagctcggtcagcaatggacaact- $3^{\prime 22}$; mitoferrin2: Fw: $5^{\prime}$ ctgcgtgatgtaccccatcg-3', Rv: $5^{\prime}$-cctgttgctgtgacgttcag- $3^{\prime 23}$; and $\beta$-actin Fw: $5^{\prime}$-cagcggaaccgctcattgccaatgg-3', Rv: 5' -tcacccacactgtgcccatctacga- $3^{\prime}$.

\section{OXPHOS Measurement}

Mitochondrial respiratory chain complex activities were measured in skeletal fibroblasts by standard spectrophotometric assays. $^{24}$

\section{Oxygen Consumption Rate Measurements}

The assays were performed as previously described, ${ }^{19}$ using $2 \times 10^{4}$ myoblasts/well in XF96 plates (Seahorse Bioscience) to evaluate the cellular $\mathrm{O}_{2}$ consumption in a Seahorse Bioscience XF96 extracellular flux analyzer.

\section{Mitochondrial Enrichment of Myoblasts and Fibroblasts}

Approximately $2 \times 10^{6}$ cells were trypsinized, washed in cold $1 \times$ phosphate-buffered saline, and lysed in buffer A (250 mM saccharose, $20 \mathrm{mM}$ Tris-base, $40 \mathrm{mM} \mathrm{KCl}$, and $2 \mathrm{mM}$ EGTA
$\mathrm{pH}$ 7.2) supplemented with $1 \mathrm{mg} / \mathrm{mL}$ bovine serum albumin (BSA), 10\% wt/vol Percoll, and 0.01\% wt/vol digitonin for 10 minutes on ice. Cells were spun down 5 minutes at $5,000 \mathrm{~g}$ in a tabletop centrifuge. The pellet was harvested and washed in buffer $\mathrm{A}+1 \mathrm{mg} / \mathrm{mL}$ BSA, further spun down, and finally lysed in buffer $\mathrm{M}$ (50 mM Tris-Cl pH 7.5, $100 \mathrm{mM} \mathrm{NaCl}, 50 \mathrm{mM}$ $\mathrm{NaF}, 40 \mathrm{mM} \beta$-glycerophosphate, $5 \mathrm{mM}$ EDTA, and $1 \%$ Triton-X100) 20 minutes on ice. Enriched mitochondrial membranes were harvested by centrifugation at $10,000 \mathrm{~g}$ for 10 minutes at $4^{\circ} \mathrm{C}$ and finally boiled in sample buffer with reducing agent.

\section{Western Blotting}

Lysis of myoblasts and fibroblasts was performed as previously described. ${ }^{19}$ Primary antibodies anti-LC3-B (clone 4E12, 1:1,000; MBL International, Woburn, MA) and anti$\beta$-actin (sc-81178; Santa Cruz Biotechnology, Dallas, TX) were detected with horseradish peroxidase-conjugated secondary antibody and enhanced chemiluminescence detection. Lipoic acid (Abcam ab18724 1:800) and SDH-A (Abcam ab14715 1:2,000) were used after mitochondrial enrichment as described above.

\section{FGF-21 Measurements}

Plasma from 4 healthy controls and FDX1L and ISCUdeficient individuals was used to perform ELISA measurements (Quantikine ELISA, Human FGF-21; R\&D Systems, Bio-Techne, Minneapolis, MN) as previously described. ${ }^{19}$

\section{Data Availability}

Cells and raw data sets are available on reasonable request. 
Figure 2 Muscle Biopsy of Patient 2
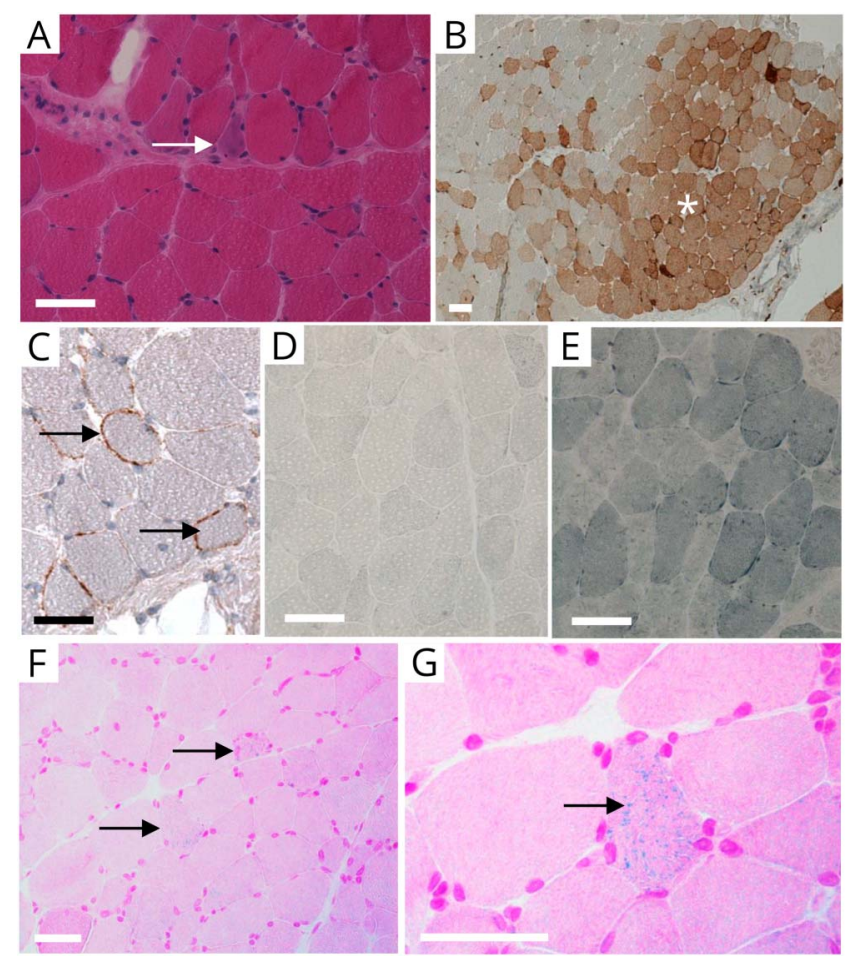

(A) Mild myopathic changes with centronucleated fibers and perifascicular basophilic fiber (arrow). (B) CD56/NCAM immunostaining showing large area of grouped positive regenerating fibers (star). (C) Membrane attack complex/C5b9 immunostaining showing rabbit poop deposits (arrows) at the surface of nonnecrotic fibers. (D and E) Histoenzymatic reaction for succinyl dehydrogenase (SDH) showing decreased SDH activity in patient (D) compared with control (E). ( $\mathrm{F}$ and $\mathrm{G})$ Perls staining showing mild iron $\left(\mathrm{Fe}^{3+}\right)$ overload in some myofibers ( $F$; arrows); higher magnification showing the punctuated appearance of iron deposition (G; arrow) corresponding to the intracellular location of mitochondria.

\section{Results}

\section{Clinical and Biological Phenotype}

Two female individuals aged 21 (P1-FDX2) and 18 (P2ISCU) years were the subjects of the study. A few biological data of P1 have been briefly reported in a large cohort of patients with variants within the Fe-S cluster or the lipoic acid biosynthesis pathways. ${ }^{18}$ These patients were born from related families of Romanian and French (Guadeloupe) origin, respectively. P1 lost her sister at age 16 years from the same disease, during an episode of RM and lactic acidosis. Both individuals $\mathrm{P} 1$ and $\mathrm{P} 2$ were born at term, with height and weight in the normal range as well as motor and cognitive development. They obtained their general bachelor's degree.

They have recurrent RM episodes precipitated by febrile illnesses, fasting, exercise, cold, or fatigue, sometimes without trigger, associated with palpitations and dyspnea related to lactic acidosis. The first episode occurred at age 6 years in P1 and 14 years in P2, associated with lactic acidosis. The presenting symptoms were generalized weakness, inability to walk, myalgia, polypnea, and dark urine. The reflexes were usually preserved. The CNS was typically spared during the episodes. In P1, the number of RMs was 2-3 per year until age 12 years; then, the frequency has gradually decreased, without recurrence since age 18 years. Renal failure was frequently associated. Cardiac arrest occurred in 1 episode. $\mathrm{P} 2$ presented with 9 episodes of RM since age 14 years. At disease onset, a facial edema with transient malar erythema was associated with P2 RM. Both patients displayed 1 episode of pulmonary embolism at age 18 years. During acute $\mathrm{RM}$, plasma creatine kinase (CK) levels were markedly elevated (maximum peak levels 105,000 U/L in P1, 200,000 U/L in P2, $\mathrm{N}<200 \mathrm{U} / \mathrm{L}$ ) with overt myoglobinuria. Lactate dehydrogenase and aspartate aminotransferase were concomitantly elevated (data not shown) as well as lactate concentrations in blood (4-23 mmol/L; $\mathrm{N}<2.2 \mathrm{mmol} / \mathrm{L}$ ) and acidosis (i.e., $\mathrm{pH} 6.80$ ). During the episodes, treatment with IV fluids and alkalinization was proposed, associated in a few cases with dialysis.

Between episodes, the individuals presented generalized weakness, more pronounced in P1 who had muscle pain worsened by mild effort, predominantly in the lower limbs, an amyotrophy, and a mild muscle deficit. The walking perimeter was $100-150 \mathrm{~m}$ without assistance for P1, and longer for P2, who was able to go to school by herself. CK levels were normal or subnormal in both individuals. Sensory and motor nerve conductions were normal, and needle EMG showed a myogenic pattern in both patients. The P1 leg muscle MRI showed fatty infiltration at age 12 years. Echocardiogram was normal in both patients. Cardiopulmonary exercise tests were performed in P1 and P2 at age 18 years. ${ }^{25}$ Both tests were maximal, as suggested by the ventilatory ratio $>1.1$ and the effort intensity score (on the modified Borg scale graduated from 0 to 10$)>8$. P1 reached a peak oxygen uptake equal to $5.8 \mathrm{~mL} / \mathrm{kg} / \mathrm{min}$ ( $18 \%$ of theoretical value), whereas $\mathrm{P} 2$ reached an oxygen uptake equal to $12.7 \mathrm{~mL} / \mathrm{kg} / \mathrm{min}$ ( $40 \%$ of theoretical value), indicating a much more impaired adaptation of peripheral muscle in P1.

Amino acid analysis in P1 plasma showed constant elevation of alanine and mild decrease of branched chain amino acids, whereas it was normal in P2 plasma. In urine, lactate and alpha-ketoglutarate were detected at higher levels in P1 than in P2. Normal results were obtained for total and free carnitine and blood acylcarnitine profile.

In P1, the administration of coenzyme Q10 and vitamins including riboflavin and thiamine did not prevent RM. In P2, administration of steroids for 4 months and methotrexate for an initial clinical suspicion of dermatomyositis did not improve the patient. Her antibodies were negative ( $\mathrm{RaCh}$, MuSK, and MSA).

\section{Muscle Pathology}

In P1, a first muscle biopsy realized at age 6 years was considered as normal in terms of pathologic findings (data not shown). A second deltoid biopsy performed at age 18 years (Figure 1) revealed slight mitochondrial (fuchsinophile) subsarcolemma overload (A), an important lipid accumulation (B), a predominance of fibers type 1 (C), an absence of 
A

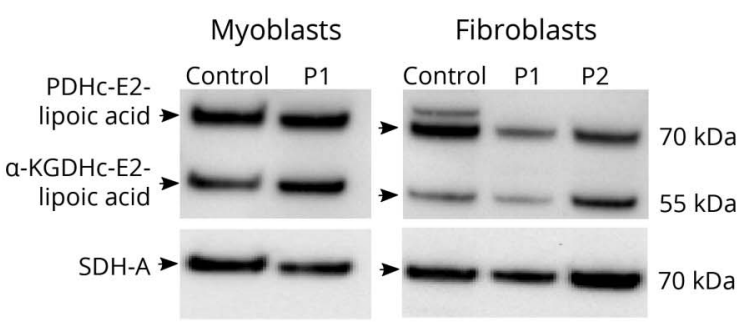

B. Myoblasts

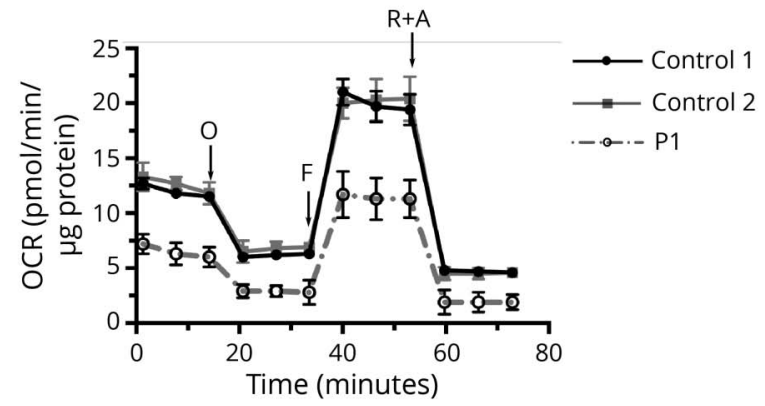

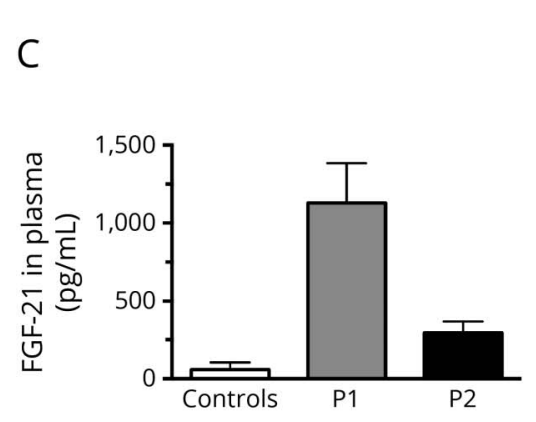

F. P2 muscle vs controls

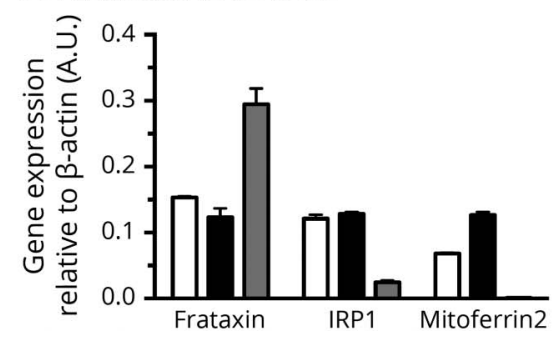

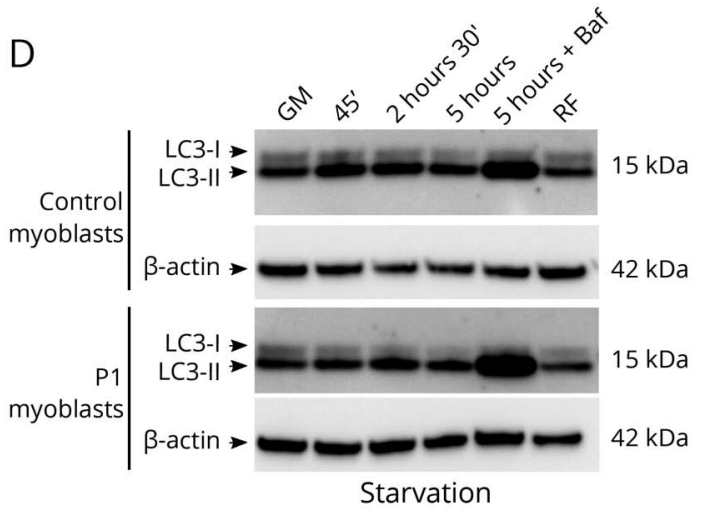

$\mathrm{E}$

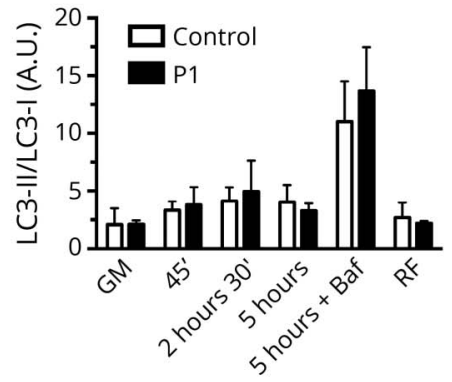

G. P1 myoblasts vs controls

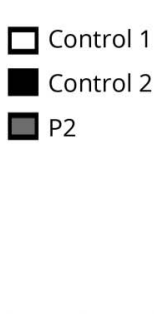

(A) Lipoic acid was detected in the mitochondrial-enriched fraction of myoblasts (left panel) or fibroblasts (right panel). Succinyl dehydrogenase (SDH)-A was used as loading control. Gels are representative of $n=3$ independent experiments with similar results. (B) The oxygen consumption rate (OCR) of 2 controls and P1 myoblasts was evaluated by Seahorse experiments on stimulation with olygomycin $(\mathrm{O}), \mathrm{FCCP}(\mathrm{F})$, and rotenone + antimycin $A(R+A)$ at the indicated time points. Data represent a single experiment with $n=5$ technical replicates per point $+S E M$, out of $n=3$ independent experiments. (C) Plasma from control individuals $(n=4), P 2$, and P1 was used to measure FGF-21. For P1 and P2, data represent mean and SEM of $n=2$ independent blood tests in technical triplicates. (D) Control or P1 myoblasts were incubated in growth medium (GM), starved in Earle's balanced salt solution for the indicated time points with or without bafilomycin A (Baf), or refed with growth medium for 2 hours, after 5 hours of starvation (RF). After lysis and washing, LC3 lipidation was detected by Western blotting. $\beta$-Actin was used as loading control. (E) Quantification of LC3 lipidation as on D. Bars are mean + SEM of $n=3$ independent experiments. (F) RNA was extracted from muscle biopsies of 2 control individuals and from P2. After reverse transcription, the gene expression levels of frataxin (FXN), IRP1, and mitoferrin 2 were evaluated by quantitative reverse transcription $\mathrm{PPCR}$, using $\beta$-actin as a housekeeping gene. Data represent $2^{-(\Delta C t)}$ of each gene relative to $\beta$-actin. Bars are mean + SEM of $n=3$ technical replicates. (G) RNA was extracted from 2 control myoblasts or P1. After reverse transcription, the gene expression was evaluated as above. Data represent $2^{-(\Delta \Delta \mathrm{Ct})}$ relative to 2 controls set at $2^{-(\Delta \Delta \mathrm{Ct})}=1$ (dashed line). Each dot represents an individual experiment, out of $\mathrm{n}=3$ independent experiments.

cytochrome c oxidase coloration in a few fibers (D), an almost complete absence of SDH enzyme activity in muscle fibers (E), and no iron deposit in Perls coloration (F). Ultrastructural study showed the presence of abnormal mitochondria containing palisade crystals, proliferation of mitochondrial crests with osmiophilic inclusions in some mitochondria, and numerous lipid droplets (G-I).

In P2, deltoid muscle biopsy performed at age 18 years (Figure 2) showed mild myopathic changes with centronucleated fibers and perifascicular basophilic fiber (A).
CD56/NCAM immunostaining showed large area of grouped positive regenerating fibers (B). Membrane attack complex/ C5b9 immunostaining showed deposits at the surface of nonnecrotic fibers (C). Histoenzymatic reaction for SDH showed decreased SDH activity compared with control (D and $\mathrm{E})$. Perls staining showed mild iron $\left(\mathrm{Fe}^{3+}\right)$ overload in some myofibers (F and G).

\section{Molecular Investigations}

We first excluded fatty acid oxidation defects by biochemical investigation in both individuals (data not shown). Subsequently, 
genomic DNA from both patients was investigated by using whole-exome sequencing (P1) and a panel of genes involved in $\mathrm{RM}$ by next-generation sequencing (P2). Only 1 candidate gene per patient was retained by its function and by variants found, FDX2 (P1), and ISCU (P2). In P1, the homozygous variant c.1A>T in FDX2 (NM_001031734.2), previously reported in another patient, ${ }^{6}$ was found, causing the loss of the primary start codon. In $\mathrm{P} 2$, the homozygous variant c.418+382 G>C (NM_213595.3) in intron 4 in ISCU was noted, as already reported. ${ }^{3,9,17,26-28}$ Both the next-generation sequencing of the dedicated RM panel of genes (P1) and the Sanger sequencing (P1 and P2) confirmed these variants in both individuals and indicated that the parents were heterozygous for 1 of them. Healthy siblings had no variant or only 1 heterozygous variant (data not shown). The deceased sibling of P1 was not tested.

\section{FDX2 and ISCU Variants Cause Mitochondrial Dysfunction}

Considering the key role of both genes in mitochondrial homeostasis, we suspected that key mitochondrial functions might be perturbed in the absence of functional FDX2 and ISCU protein. Therefore, we investigated and compared when possible different mitochondrial tests including respiratory chain enzymes by spectrophotometry, mitochondrial lipoylated proteins by immunoblotting, oxygen consumption by the Seahorse technology in patient myoblasts, and FGF-21. ${ }^{29}$

The enzymatic activities of the mitochondrial respiratory chain complexes were realized in fibroblasts of both patients (P1 with FDX2 variants and $\mathrm{P} 2$ with ISCU variants). The results showed a moderated decrease of complex I activity and lipoylated PDHc in fibroblasts of P1, whereas complex II, complex III, $\alpha-\mathrm{KGDHc}$, and aconitase activities were normal. ${ }^{18}$ In fibroblasts of $\mathrm{P} 2$, results were normal for all mitochondrial complexes and for $\alpha$-KGDHc activity (data not shown).

The lipoylation levels of the E2 subunit of PDHc and $\alpha-K G D H c$ were not altered in fibroblasts of both individuals (Figure 3A, right panel) in agreement with a previous report on P1 fibroblasts. ${ }^{18}$ No difference was observed in both individuals, deficient for either FDX1L or ISCU proteins. Importantly, the lipoylation normality was not due to the choice of the tissue as it was also normal in FDX2-deficient myoblasts (Figure 3A, left panel).

Oxygen consumption rates decreased in FDX2-deficient myoblasts, even in basal conditions (Figure 3B). These results correlated with the decreased oxygen uptake by peripheral muscle during the effort test that was worsened in P1 than in P2 and with the result of FGF-21 measured in basal condition that was very elevated in plasma of $\mathrm{P} 1$ and moderately increased in P2 (Figure 3C). These observations strongly suggest a greater respiratory capacity failure downstream of mutated FDX2 than mutated ISCU.

\section{Variants in FDX2 Individuals Do Not Cause Defective Mitophagic Clearance}

We speculated that FDX2 and ISCU diseases might perturb mitophagy, as adenosine triphosphate (ATP) is required for initiation and progression of macroautophagy ${ }^{30}$ and for degradation of soluble cytosolic proteins in lysosomes. ${ }^{31}$ Thus, we examined the consequence of a loss of FDX2 in the activity of autophagy, by determining the regulation of the autophagosomal marker LC3 level in basal conditions, starvation (Earle's balanced salt solution [EBSS]), and refeeding. Immunoblot revealed the presence of LC3 II staining in fasting condition (EBSS) in control and patient myoblasts deficient for FDX2, suggesting correct induction of autophagy (Figure 3, D and E). Moreover, the accumulation of LC3-II was similar after blocking autophagosome degradation by bafilomycin, and LC3 II level normalized in individuals' myoblasts after refeeding. Thus, autophagic flux was not altered by the absence of FDX2.

\section{Iron Pathway}

The ISCU-deficient skeletal muscle (P2) showed a histology pattern of iron overload, whereas the FDX2-deficient muscle (P1) did not. Iron is transported into cells on its ferric form $\left(\mathrm{Fe}^{3+}\right)$ after binding to the cytosolic transferrin receptor. Transcriptional regulation of iron-responsive proteins was investigated in skeletal muscle (P2) or myoblasts (P1) relative to controls, including IRP1 (aconitase 1 that regulates import of iron into cells by modulating transferrin), mitoferrin2 (a mitochondrial iron transporter that mediates iron transport across the mitochondrial inner membrane), and FXN (a mitochondrial protein involved in assembly of Fe-S clusters and in iron storage protein). In agreement with the iron overload in P2, mitoferrin2 and IRP1 gene expression was downregulated in P2's skeletal muscle relative to 2 control muscles, at the same time that $F X N$ gene expression was upregulated (Figure 3F). In the absence of P1 skeletal muscle, we performed similar experiments in myoblasts from P1 (Figure 3G), where we found no significant up- or downregulation of any of the above genes.

\section{Discussion}

De novo synthesis of the $2 \mathrm{Fe}-2 \mathrm{~S}$ cluster is accomplished on the scaffold protein $\operatorname{ISCU}^{14,32,33}$ with the help of FDX2 $2^{34,35}$ and FXN that form a dynamic complex with ISCU. ${ }^{36,37}$ In humans, ISCU deficiency has been widely reported, whereas FDX2 variants have been reported at least twice. Contrary to other diseases involving the ISC assembly machinery, the phenotype resulting from variants in either ISCU or FDX2 is mainly restricted to skeletal muscle. ${ }^{8,12}$ Here, we report 2 individuals with recessively inherited variants in either ISCU or FDX2 genes, with recurrent episodes of RM associated with muscle weakness and lactic acidosis. Except the onset of RM and a ptosis noted in P2, the clinical phenotype was similar in both individuals, although more severe in FDX2-deficient patient. 
According to the clinical phenotype, the biochemical phenotype and the effort test were also more severe in FDX2 deficiency than in ISCU deficiency, with an increase of blood FGF-21 that was more pronounced in P1 than in P2 and a greater decrease of oxygen uptake by peripheral muscle during effort tests. We also found a decrease in mitochondrial respiratory chain complex I and PDHc activities ${ }^{18}$ in P1 fibroblasts. The mitochondrial respiratory chain complexes II and III were normal in fibroblasts from both individuals, although they were markedly decreased in previously reported patients with FDX2 or ISCU deficiency. ${ }^{5,6}$ In P1 myoblasts, basal respiration, spare respiratory capacity, and ATP production were severely reduced compared with healthy controls, strengthening the observations obtained previously in fibroblasts. ${ }^{18}$ On that report, we showed that unexpectedly, PDHc-E2 and $\alpha$-KDGHc-E2 were correctly lipoylated in the absence of FDX2, as opposed to several other Fe-S clusterforming proteins. Here, we verified that finding, extended it to ISCU-deficient fibroblasts, and verified tissue independence by showing correct lipoylation in FDX2-deficient myoblasts. If lipoylation is considered as a proxy of ISC maturation, these data imply that both ISCU and FDX2 are redundant in Fe-S biogenesis. However, $\mathrm{P} 1$ has a severe phenotype, whereas her sister bearing the same variation already died. A possible explanation may rely on the second ferredoxin FDX1, which is also important for ISC biogenesis. ${ }^{6,34,35}$ Concerning ISCU protein, almost absent in muscle tissue from ISCU-deficient patients, it was present in other examined tissues. ${ }^{3,4,16}$ Therefore, the tissue specificity in ISCU myopathy can be attributed to several factors, including tissue and differentiation-specific abnormal mRNA splicing ${ }^{15,16,38}$ that our patient shares.

Alternatively, and beyond tissue specificity, both ISCU and FDX2 might have another function in addition to ISC biogenesis. Indeed, oxidative stress destabilizes the small amounts of normal ISCU protein generated in patient's skeletal muscles. ${ }^{15}$ On that line, we suspected that mitophagy, a selective form of autophagy that specifically targets mitochondria through autophagolysosomal activity in response to the stresses, ${ }^{39}$ could also be affected in the absence of ISCU or FDX2. Indeed, mitophagy can be impaired as ATP is required for initiation and progression of macroautophagy ${ }^{30}$ or for degradation of soluble cytosolic proteins in lysosomes. ${ }^{31}$ Moreover, our ongoing investigations indicate that autophagy deficiency is linked with development of RM events in other genetic backgrounds. ${ }^{40}$ Unfortunately, we failed to see any alteration in autophagic flux of FDX2-deficient myoblasts, indicating that autophagy alteration is not a core molecular marker for RM events. In the absence of P2 myoblasts, we cannot extend the same statement to ISCU, although it is unlikely to have a major autophagic defect in a relatively milder disease scenario.

Another difference between both individuals with variants in either ISCU or FDX2 genes was the muscle biopsy findings. Both showed a specific decreased SDH coloration, but only ISCU myopathy was associated with an iron load. Under normal conditions, on increase in iron concentration, the mRNA synthesis of the transferrin receptor is downregulated and vice versa. IRP1 (aconitase 1) controls import of iron in cells by modulating transferrin, whereas mitoferrin2, a mitochondrial iron transporter, mediates iron transport across the mitochondrial inner membrane. The intracellular iron overload in ISCU (P2) skeletal muscle was associated with a decrease in IRP1, as already reported ${ }^{3,15,41}$ and a decrease of mitoferrin2 gene expression that is in contradiction with another study. ${ }^{41}$ These results are consistent with a musclespecific alteration of iron homeostasis in this disease compared with FDX2 disease. Whether gene regulation is a cause or a consequence cannot be established from our experiments. However, we favor the hypothesis of an initial iron load coming from the extracellular milieu that cannot be passed through the ISC biogenesis chain; in turn, iron will accumulate inside the cell, thereby downregulating genes necessary for iron import. Compared with P2, we found that in P1 myoblasts, there was no modification of IRP1 or mitoferrin 2 , confirming the absence of iron accumulation in skeletal muscle of this patient.

Like in P1 myoblasts in which FXN tended to be upregulated, there is a clear upregulation of such gene in P2 muscle cells. ${ }^{42} \mathrm{FXN}$ is a mitochondrial protein involved in assembly of Fe-S clusters through its interaction with the ISCU-NFS1ISD11 complex, ${ }^{43,44}$ but also in iron storage or as an iron chaperone. Its deficiency leads to ISC deficiency, mitochondrial dysfunction, ${ }^{45}$ and major mitochondrial iron accumulation. ${ }^{45,46}$ Because FXN binds ISCU ${ }^{47}$ and stimulates persulfide transfer to ISCU, ${ }^{48}$ it might act as a compensatory protein to fulfill the demand for $\mathrm{Fe}-\mathrm{S}$ biogenesis, altered in case of ISCU deficiency. ${ }^{42}$ It might be interesting to know whether in Friedreich ataxia (FRDA), where FXN expression is insufficient, ISCU might play a compensatory effect. In the case of FDX2, FXN might also mildly compensate for its absence, although from our experiments, this is not totally evident despite a trend. However, since FDX2 intervenes only after FXN in the ISC machinery, it could be expected that FXN does not compensate FDX2 deficiency. ${ }^{48}$ Of interest, the increased iron uptake in FRDA is related to marked transferrin receptor 1 and mitoferrin 2 upregulations that facilitate mitochondrial iron influx and a decreased expression of the iron exporter, ferroportin 1, leading to decreased cellular iron efflux. ${ }^{49-51}$ Thus, we can conclude by our findings that ISCU deficiency and FRDA differ by the expression of IRP1.

In conclusion, variants in FDX2 and ISCU genes lead to a similar phenotype associating RM, muscle weakness, and lactic acidosis, which is more severe in the FDX2 individual. The phenotype is partially related as a common energy deficiency, with P1 showing more mitochondrial-derived inflammation (FGF-21) but no iron accumulation and functional autophagy, whereas P2 shows iron accumulation followed by a regulation of iron regulatory genes, and mild FGF-21 production. Our data confirm that FDX2 is not 
involved in mitochondrial iron influx contrary to FXN. In ISCU deficiency, IRP1 downregulation and FXN upregulation also suggest that ISCU is not involved in mitochondrial iron influx. Further studies should focus on the potential effects of iron chelators to modulate ISCU absence.

\section{Acknowledgment}

The authors thank Ivan Nemazzany of the metabolic platform SFR-Necker for assistance with SeaHorse experiments, Christine Bole-Feysot for exome analysis, and Clémence Labasse for the excellent electron microscopy techniques.

\section{Study Funding}

This work was supported by grants to P. de Lonlay from Agence Nationale de la Recherche (ANR-AAPG 2018 CE17 MetabInf), the Association Française contre les Myopathies (AFM 2016-2018 19773), and patient associations (Nos Anges, AMMI, OPPH, No Myolyse, Hyperinsulinisme, Noa Luû). S. Montealegre was supported by a funding from the ANR-AAPG 2018 CE17 MetabInf.

\section{Disclosure}

The authors report no disclosures. Go to Neurology.org/NG for full disclosures.

\section{Publication History}

Received by Neurology: Genetics February 23, 2021. Accepted in final form October 18, 2021.

Appendix Authors

\begin{tabular}{|c|c|c|}
\hline Name & Location & Contribution \\
\hline $\begin{array}{l}\text { Sebastian } \\
\text { Montealegre, } \\
\text { PhD }\end{array}$ & $\begin{array}{l}\text { Inserm U1151, Institut } \\
\text { Necker Enfants-Malades, } \\
\text { Paris, France; Reference } \\
\text { Center of Inherited } \\
\text { Metabolic Diseases, Necker- } \\
\text { Enfants-Malades University } \\
\text { Hospital, APHP, Imagine } \\
\text { Institute, Paris University, } \\
\text { Filière G2M, France }\end{array}$ & $\begin{array}{l}\text { Drafting/revision of the } \\
\text { manuscript for content, } \\
\text { including medical writing for } \\
\text { content; major role in the } \\
\text { acquisition of data; study } \\
\text { concept or design; and } \\
\text { analysis or interpretation of } \\
\text { data }\end{array}$ \\
\hline $\begin{array}{l}\text { Elise Lebigot, } \\
\text { MD, PhD }\end{array}$ & $\begin{array}{l}\text { Biochemistry Laboratory, } \\
\text { Filière G2M, Bicêtre } \\
\text { Hospital, APHP Paris Saclay, } \\
\text { Le Kremlin Bicêtre, France }\end{array}$ & $\begin{array}{l}\text { Drafting/revision of the } \\
\text { manuscript for content, } \\
\text { including medical writing for } \\
\text { content, and analysis or } \\
\text { interpretation of data }\end{array}$ \\
\hline $\begin{array}{l}\text { Hugo } \\
\text { Debruge, BSc }\end{array}$ & $\begin{array}{l}\text { Inserm U1151, Institut } \\
\text { Necker Enfants-Malades, } \\
\text { Paris, France }\end{array}$ & $\begin{array}{l}\text { Major role in the acquisition } \\
\text { of data }\end{array}$ \\
\hline $\begin{array}{l}\text { Norma } \\
\text { Romero, MD, } \\
\text { PhD }\end{array}$ & $\begin{array}{l}\text { Neurology Unit, Trousseau } \\
\text { Hospital, APHP, Filière G2M, } \\
\text { Paris, France }\end{array}$ & $\begin{array}{l}\text { Analysis or interpretation of } \\
\text { data }\end{array}$ \\
\hline $\begin{array}{l}\text { Bénédicte } \\
\text { Héron, MD }\end{array}$ & $\begin{array}{l}\text { Neurology Unit, Trousseau } \\
\text { Hospital, APHP, Filière G2M, } \\
\text { Paris, France }\end{array}$ & $\begin{array}{l}\text { Patient management, } \\
\text { analysis and interpretation } \\
\text { of data }\end{array}$ \\
\hline $\begin{array}{l}\text { Pauline } \\
\text { Gaignard, } \\
\text { MD, PhD }\end{array}$ & $\begin{array}{l}\text { Biochemistry Laboratory, } \\
\text { Filière G2M, Bicêtre } \\
\text { Hospital, APHP Paris Saclay, } \\
\text { Le Kremlin Bicêtre, France }\end{array}$ & $\begin{array}{l}\text { Analysis or interpretation of } \\
\text { data and OXPHOS studies }\end{array}$ \\
\hline
\end{tabular}

Appendix (continued)

\begin{tabular}{lll}
\hline Name & Location & Contribution \\
\hline Antoine & M3C-Necker, Congenital & Effort test \\
Legendre, & and Pediatric Cardiology, & \\
MD, PhD & Hôpital Universitaire & \\
& Necker-Enfants Malades, \\
& Paris, France &
\end{tabular}

\begin{tabular}{ll}
\hline $\begin{array}{l}\text { Apolline } \\
\text { Imbard, MD, }\end{array}$ & Reference Center of \\
PhD & Inherited Metabolic \\
& Diseases, Necker-Enfants- \\
& Malades University Hospital, \\
& APHP, Imagine Institute, \\
& Paris University, Filière G2M, \\
& France; Biochemistry \\
& Department, Necker- \\
& Enfants-Malades University \\
& Hospital, APHP, Paris \\
& University, France \\
\end{tabular}

\begin{tabular}{ll}
\hline Stéphanie & Genetics Department, \\
Gobin, PhD & Necker-Enfants-Malades \\
& University Hospital, APHP, \\
& Paris, France
\end{tabular}

Emmanuelle Sorbonne Universié, UPMC, Pathology

Lacène, BSc INSERM UMR974, Center for

Research in Myology,

Neuromuscular

Morphology Unit, Myology

Institute, AP-HP, East-Paris

Reference Center of

neuromuscular diseases,

GHU Pitié-Salpêtrière,

France

\begin{tabular}{|c|c|c|}
\hline $\begin{array}{l}\text { Patrick } \\
\text { Nusbaum, } \\
\text { PhD }\end{array}$ & $\begin{array}{l}\text { Genetics and Molecular } \\
\text { Biology, Laboratoire de } \\
\text { Culture Cellulaire, Hôpital } \\
\text { Cochin, Paris, France }\end{array}$ & Myoblast culture \\
\hline $\begin{array}{l}\text { Arnaud } \\
\text { Hubas, PhD }\end{array}$ & $\begin{array}{l}\text { Genetics and Molecular } \\
\text { Biology, Laboratoire de } \\
\text { Culture Cellulaire, Hôpital } \\
\text { Cochin, Paris, France }\end{array}$ & Myoblast culture \\
\hline $\begin{array}{l}\text { Isabelle } \\
\text { Desguerre, } \\
\text { MD, PhD }\end{array}$ & $\begin{array}{l}\text { Reference Center of } \\
\text { Neuromuscular Diseases, } \\
\text { Necker-Enfants-Malades } \\
\text { University Hospital, APHP, } \\
\text { Filière Filnemus, Paris, } \\
\text { France }\end{array}$ & $\begin{array}{l}\text { Patient management, } \\
\text { analysis and interpretation } \\
\text { of data }\end{array}$ \\
\hline
\end{tabular}

\begin{tabular}{|c|c|c|}
\hline $\begin{array}{l}\text { Aude Servais, } \\
\text { MD, PhD }\end{array}$ & $\begin{array}{l}\text { Reference Center of } \\
\text { Inherited Metabolic } \\
\text { Diseases, Necker-Enfants- } \\
\text { Malades University Hospital, } \\
\text { APHP, Imagine Institute, } \\
\text { Paris University, Filière G2M, } \\
\text { France; Adult Nephrology \& } \\
\text { Transplantation, Necker- } \\
\text { Enfants-Malades University } \\
\text { Hospital, APHP, Inserm } \\
\text { U1163, Imagine Institute, } \\
\text { Paris Descartes University, } \\
\text { France }\end{array}$ & $\begin{array}{l}\text { Patient management, } \\
\text { analysis and interpretation } \\
\text { of data }\end{array}$ \\
\hline $\begin{array}{l}\text { Pascal } \\
\text { Laforêt, MD, } \\
\text { PhD }\end{array}$ & $\begin{array}{l}\text { Department of Neurology, } \\
\text { Raymond-Poincaré } \\
\text { Hospital, Garches, and } \\
\text { Inserm U1179 Versailles } \\
\text { Saint-Quentin-en-Yvelines } \\
\text { University, Montigny-le- } \\
\text { Bretonneux, France }\end{array}$ & $\begin{array}{l}\text { Patient management, } \\
\text { analysis and interpretation } \\
\text { of data }\end{array}$ \\
\hline $\begin{array}{l}\text { Peter van } \\
\text { Endert, MD, } \\
\text { PhD }\end{array}$ & $\begin{array}{l}\text { Inserm U1151, Institut } \\
\text { Necker Enfants-Malades, } \\
\text { Paris, France }\end{array}$ & Supervision \\
\hline
\end{tabular}

Biochemical and FGF21 studies

(n)

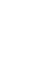


Appendix (continued)

\begin{tabular}{|c|c|c|}
\hline Name & Location & Contribution \\
\hline $\begin{array}{l}\text { François } \\
\text { Jérome } \\
\text { Authier, MD, } \\
\text { PhD }\end{array}$ & $\begin{array}{l}\text { Reference Center for } \\
\text { Neuromuscular Disorders, } \\
\text { Department de Pathologie, } \\
\text { Henri Mondor Hospital, } \\
\text { APHP, IMRB U955, Faculty of } \\
\text { Medicine, Creteil, France }\end{array}$ & $\begin{array}{l}\text { Analysis or interpretation of } \\
\text { data and pathology }\end{array}$ \\
\hline $\begin{array}{l}\text { Cyril Gitiaux, } \\
\text { MD, PhD }\end{array}$ & $\begin{array}{l}\text { Reference Center of } \\
\text { Neuromuscular Diseases, } \\
\text { Necker-Enfants-Malades } \\
\text { University Hospital, APHP, } \\
\text { Filière Filnemus, Paris, } \\
\text { France; Reference Center } \\
\text { for Neuromuscular } \\
\text { Disorders, Department de } \\
\text { Pathologie, Henri Mondor } \\
\text { Hospital, APHP, IMRB U955, } \\
\text { Faculty of Medicine, Creteil, } \\
\text { France }\end{array}$ & $\begin{array}{l}\text { Analysis or interpretation of } \\
\text { data }\end{array}$ \\
\hline $\begin{array}{l}\text { Pascale de } \\
\text { Lonlay, MD, } \\
\text { PhD }\end{array}$ & $\begin{array}{l}\text { Inserm U1151, Institut } \\
\text { Necker Enfants-Malades, } \\
\text { Paris, France; Reference } \\
\text { Center of inherited } \\
\text { Metabolic Diseases, Necker- } \\
\text { Enfants-Malades University } \\
\text { Hospital, APHP, Imagine } \\
\text { Institute, Paris University, } \\
\text { Filière G2M, France }\end{array}$ & $\begin{array}{l}\text { Drafting/revision of the } \\
\text { manuscript for content, } \\
\text { including medical writing for } \\
\text { content; study concept or } \\
\text { design; and analysis or } \\
\text { interpretation of data }\end{array}$ \\
\hline
\end{tabular}

\section{References}

1. Zutt R, van der Kooi AJ, Linthorst GE, Wanders RJ, de Visser M. Rhabdomyolysis: review of the literature. Neuromuscul Disord. 2014;24(8):651-659.

2. Milone M, Wong LJ. Diagnosis of mitochondrial myopathies. Mol Genet Metab. 2013; 110(8):35-41.

3. Mochel F, Knight MA, Tong WH, et al. Splice mutation in the iron-sulfur cluster scaffold protein ISCU causes myopathy with exercise intolerance. Am J Hum Genet. 2008;82(3):652-660.

4. Kollberg G, Tulinius M, Melberg A, et al. Clinical manifestation and a new ISCU mutation in iron-sulphur cluster deficiency myopathy. Brain. 2009;132(pt 8): 2170-2179.

5. Legati A, Reyes A, Ceccatelli Berti C, et al. A novel de novo dominant mutation in ISCU associated with mitochondrial myopathy. J Med Genet. 2017;54(12):815-824.

6. Spiegel R, Saada A, Halvardson J, et al. Deleterious mutation in FDX1L gene is associated with a novel mitochondrial muscle myopathy. Eur J Hum Genet. 2014; 22(7):902-906

7. Cameron JM, Janer A, Levandovskiy V, et al. Mutations in iron-sulfur cluster scaffold genes NFU1 and BOLA3 cause a fatal deficiency of multiple respiratory chain and 2-oxoacid dehydrogenase enzymes. Am J Hum Genet. 2011;89(4):486-495.

8. Larsson LE, Linderholm H, Mueller R, Ringqvist T, Soernaes R. Hereditary metabolic myopathy with paroxysmal myoglobinuria due to abnormal glycolysis. J Neurol Neurosurg Psychiatry. 1964;27(5):361-380.

9. Olsson A, Lind L, Thornell LE, Holmberg M. Myopathy with lactic acidosis is linked to chromosome 12q23.3-24.11 and caused by an intron mutation in the ISCU gene resulting in a splicing defect. Hum Mol Genet. 2008;17(11):1666-1672.

10. Saha PP, Kumar SK, Srivastava S, Sinha D, Pareek G, D'Silva P. The presence of multiple cellular defects associated with a novel G50E iron-sulfur cluster scaffold protein (ISCU) mutation leads to development of mitochondrial myopathy. J Biol Chem. 2014;289(15):10359-10377.

11. Drugge U, Holmberg M, Holmgren G, Almay BG, Linderholm H. Hereditary myopathy with lactic acidosis, succinate dehydrogenase and aconitase deficiency in northern Sweden: a genealogical study. J Med Genet. 1995;32(5):344-347.

12. Kollberg G, Melberg A, Holme E, Oldfors A. Transient restoration of succinate dehydrogenase activity after rhabdomyolysis in iron-sulphur cluster deficiency myopathy. Neuromuscul Disord. 2011;21(2):115-120.

13. Gurgel-Giannetti J, Lynch DS, Paiva ARB, et al. A novel complex neurological phenotype due to a homozygous mutation in FDX2. Brain. 2018;141(8):2289-2298.

14. Agar JN, Krebs C, Frazzon J, Huynh BH, Dean DR, Johnson MK. IscU as a scaffold for iron-sulfur cluster biosynthesis: sequential assembly of $[2 \mathrm{Fe}-2 \mathrm{~S}]$ and $[4 \mathrm{Fe}-4 \mathrm{~S}]$ clusters in IscU. Biochemistry. 2000;39(27):7856-7862.

15. Crooks DR, Jeong SY, Tong WH, et al. Tissue specificity of a human mitochondrial disease: differentiation-enhanced mis-splicing of the Fe-S scaffold gene ISCU renders patient cells more sensitive to oxidative stress in ISCU myopathy. J Biol Chem. 2012; 287(48):40119-40130.
16. Nordin A, Larsson E, Thornell LE, Holmberg M. Tissue-specific splicing of ISCU results in a skeletal muscle phenotype in myopathy with lactic acidosis, while complete loss of ISCU results in early embryonic death in mice. Hum Genet. 2011;129(4): 371-378.

17. Sanaker PS, Toompuu M, Hogan VE, et al. Differences in RNA processing underlie the tissue specific phenotype of ISCU myopathy. Biochim Biophys Acta. 2010; 1802(6):539-544.

18. Lebigot E, Gaignard P, Dorboz I, et al. Impact of mutations within the [Fe-S] cluster or the lipoic acid biosynthesis pathways on mitochondrial protein expression profiles in fibroblasts from patients. Mol Genet Metab. 2017;122(3):85-94.

19. Berat CM, Montealegre S, Wiedemann A, et al. Clinical and biological characterization of 20 patients with TANGO2 deficiency indicates novel triggers of metabolic crises and no primary energetic defect. J Inherit Metab Dis. 2021;44(2): 415-425.

20. Habarou F, Hamel Y, Haack TB, et al. Biallelic mutations in LIPT2 cause a mitochondrial lipoylation defect associated with severe neonatal encephalopathy. Am J Hum Genet. 2017;101(2):283-290.

21. Li K, Singh A, Crooks DR, et al. Expression of human frataxin is regulated by transcription factors SRF and TFAP2. PLoS One. 2010;5(8):e12286.

22. Deng Z, Manz DH, Torti SV, Torti FM. Iron-responsive element-binding protein 2 plays an essential role in regulating prostate cancer cell growth. Oncotarget. 2017; 8(47):82231-82243.

23. Hung HI, Schwartz JM, Maldonado EN, Lemasters JJ, Nieminen AL. Mitoferrin-2dependent mitochondrial iron uptake sensitizes human head and neck squamous carcinoma cells to photodynamic therapy. J Biol Chem. 2013;288(1):677-686.

24. Rustin $\mathrm{P}$, Chretien D, Bourgeron $\mathrm{T}$, et al. Biochemical and molecular investigations in respiratory chain deficiencies. Clin Chim Acta. 1994;228(1):35-51.

25. Legendre A, Khraiche $\mathrm{D}, \mathrm{Ou} \mathrm{P}$, et al. Cardiac function and exercise adaptation in 8 children with LPIN1 mutations. Mol Genet Metab. 2018;123(3):375-381.

26. Nordin A, Larsson E, Holmberg M. The defective splicing caused by the ISCU intron mutation in patients with myopathy with lactic acidosis is repressed by PTBP1 but can be derepressed by IGF2BP1. Hum Mutat. 2012;33(3):467-470.

27. White K, Lu Y, Annis S, et al. Genetic and hypoxic alterations of the microRNA-210ISCU1/2 axis promote iron-sulfur deficiency and pulmonary hypertension. EMBO Mol Med. 2015;7(6):695-713.

28. Rawcliffe DFR, Osterman L, Nordin A, Holmberg M. PTBP1 acts as a dominant repressor of the aberrant tissue-specific splicing of ISCU in hereditary myopathy with lactic acidosis. Mol Genet Genomic Med. 2018;6(6):887-897.

29. Suomalainen A, Elo JM, Pietilainen KH, et al. FGF-21 as a biomarker for musclemanifesting mitochondrial respiratory chain deficiencies: a diagnostic study. Lancet Neurol. 2011;10(9):806-818.

30. Schellens JP, Vreeling-Sindelarova H, Plomp PJ, Meijer AJ. Hepatic autophagy and intracellular ATP. A morphometric study. Exp Cell Res. 1988;177(1):103-108.

31. Arias E, Cuervo AM. Chaperone-mediated autophagy in protein quality control. Curr Opin Cell Biol. 2011;23(2):184-189.

32. Lill R, Hoffmann B, Molik S, et al. The role of mitochondria in cellular iron-sulfur protein biogenesis and iron metabolism. Biochim Biophys Acta. 2012;1823(9): 1491-1508.

33. Rouault TA, Maio N. Biogenesis and functions of mammalian iron-sulfur proteins in the regulation of iron homeostasis and pivotal metabolic pathways. J Biol Chem. 2017 292(31):12744-12753.

34. Sheftel AD, Stehling O, Pierik AJ, et al. Humans possess two mitochondrial ferredoxins, $\mathrm{Fdx} 1$ and $\mathrm{Fdx} 2$, with distinct roles in steroidogenesis, heme, and $\mathrm{Fe} / \mathrm{S}$ cluster biosynthesis. Proc Natl Acad Sci USA. 2010;107(26):11775-11780.

35. Shi Y, Ghosh M, Kovtunovych G, Crooks DR, Rouault TA. Both human ferredoxins 1 and 2 and ferredoxin reductase are important for iron-sulfur cluster biogenesis. Biochim Biophys Acta. 2012;1823(2):484-492.

36. Schmucker S, Martelli A, Colin F, et al. Mammalian frataxin: an essential function for cellular viability through an interaction with a preformed ISCU/NFS1/ISD11 ironsulfur assembly complex. PLoS One. 2011;6(1):e16199.

37. Webert H, Freibert SA, Gallo A, et al. Functional reconstitution of mitochondrial $\mathrm{Fe} / \mathrm{S}$ cluster synthesis on Isul reveals the involvement of ferredoxin. Nat Commun. 2014;5 5013.

38. Hall RE, Henriksson KG, Lewis SF, Haller RG, Kennaway NG. Mitochondrial myopathy with succinate dehydrogenase and aconitase deficiency. Abnormalities of several iron-sulfur proteins. J Clin Invest. 1993;92(6):2660-2666.

39. Twig G, Hyde B, Shirihai OS. Mitochondrial fusion, fission and autophagy as a quality control axis: the bioenergetic view. Biochim Biophys Acta. 2008;1777(9): 1092-1097.

40. Hamel Y, Mauvais F-X, Madrang M, et al. Compromised mitochondrial quality control triggers lipin1-related rhabdomyolysis. Cell Rep Med. 2021;2(8) 100370 .

41. Crooks DR, Natarajan TG, Jeong SY, et al. Elevated FGF21 secretion, PGC-1alpha and ketogenic enzyme expression are hallmarks of iron-sulfur cluster depletion in human skeletal muscle. Hum Mol Genet. 2014;23(1):24-39.

42. Stehling O, Wilbrecht C, Lill R. Mitochondrial iron-sulfur protein biogenesis and human disease. Biochimie. 2014;100:61-77.

43. Colin F, Martelli A, Clemancey M, et al. Mammalian frataxin controls sulfur production and iron entry during de novo Fe4S4 cluster assembly. J Am Chem Soc. 2013; 135(2):733-740

44. Tsai CL, Barondeau DP. Human frataxin is an allosteric switch that activates the Fe-S cluster biosynthetic complex. Biochemistry. 2010;49(43):9132-9139. 
45. Puccio H, Simon D, Cossee M, et al. Mouse models for Friedreich ataxia exhibit cardiomyopathy, sensory nerve defect and Fe-S enzyme deficiency followed by intramitochondrial iron deposits. Nat Genet. 2001;27(2):181-186.

46. Michael S, Petrocine SV, Qian J, et al. Iron and iron-responsive proteins in the cardiomyopathy of Friedreich's ataxia. Cerebellum. 2006;5(4):257-267.

47. Acquaviva F, De Biase I, Nezi L, et al. Extra-mitochondrial localisation of frataxin and its association with IscU1 during enterocyte-like differentiation of the human colon adenocarcinoma cell line Caco-2. J Cell Sci. 2005;118(pt 17):3917-3924.

48. Gervason $\mathrm{S}$, Larkem $\mathrm{D}$, Mansour $\mathrm{AB}$, et al. Physiologically relevant reconstitution of iron-sulfur cluster biosynthesis uncovers persulfide-processing functions of ferredoxin-2 and frataxin. Nat Commun. 2019;10(1):3566.
49. Huang ML, Becker EM, Whitnall M, Suryo Rahmanto Y, Ponka P, Richardson DR Elucidation of the mechanism of mitochondrial iron loading in Friedreich's ataxia by analysis of a mouse mutant. Proc Natl Acad Sci USA. 2009;106(38): 16381-16386.

50. Richardson DR, Huang ML, Whitnall M, Becker EM, Ponka P, Suryo Rahmanto Y. The ins and outs of mitochondrial iron-loading: the metabolic defect in Friedreich's ataxia. J Mol Med (Berl). 2010;88(4):323-329.

51. Whitnall M, Suryo Rahmanto Y, Sutak R, et al. The MCK mouse heart model of Friedreich's ataxia: alterations in iron-regulated proteins and cardiac hypertrophy are limited by iron chelation. Proc Natl Acad Sci USA. 2008;105(28): 9757-9762. 


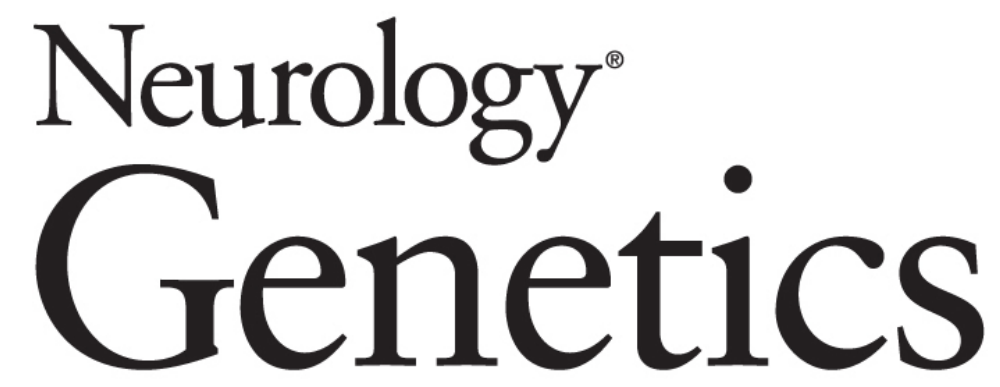

FDX2 and ISCU Gene Variations Lead to Rhabdomyolysis With Distinct Severity and Iron Regulation

Sebastian Montealegre, Elise Lebigot, Hugo Debruge, et al. Neurol Genet 2022;8;

DOI 10.1212/NXG.0000000000000648

This information is current as of January 19, 2022

Neurol Genet is an official journal of the American Academy of Neurology. Published since April 2015, it is an open-access, online-only, continuous publication journal. Copyright Copyright $\odot 2022$ The Author(s). Published by Wolters Kluwer Health, Inc. on behalf of the American Academy of Neurology.. All rights reserved. Online ISSN: 2376-7839.

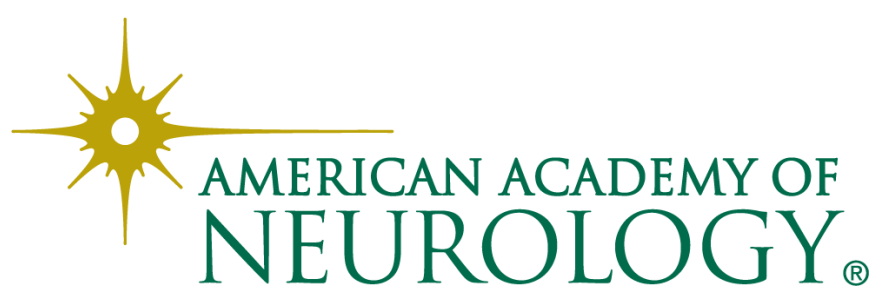




\section{Updated Information \& Services}

References

Subspecialty Collections

\section{Permissions \& Licensing}

Reprints including high resolution figures, can be found at: http://ng.neurology.org/content/8/1/e0648.full.html

This article cites 51 articles, 12 of which you can access for free at: http://ng.neurology.org/content/8/1/e0648.full.html\#\#ref-list-1

This article, along with others on similar topics, appears in the following collection(s):

Metabolic disease (inherited)

http://ng.neurology.org//cgi/collection/metabolic_disease_inherited Mitochondrial disorders

http://ng.neurology.org//cgi/collection/mitochondrial_disorders Mitochondrial disorders; see Genetics/Mitochondrial disorders http://ng.neurology.org//cgi/collection/mitochondrial_disorders_see_ge netics-mitochondrial_disorders

Muscle disease

http://ng.neurology.org//cgi/collection/muscle_disease

Information about reproducing this article in parts (figures,tables) or in its entirety can be found online at:

http://ng.neurology.org/misc/about.xhtml\#permissions

Information about ordering reprints can be found online: http://ng.neurology.org/misc/addir.xhtml\#reprintsus

Neurol Genet is an official journal of the American Academy of Neurology. Published since April 2015, it is an open-access, online-only, continuous publication journal. Copyright Copyright $\odot 2022$ The Author(s). Published by Wolters Kluwer Health, Inc. on behalf of the American Academy of Neurology.. All rights reserved. Online ISSN: 2376-7839.

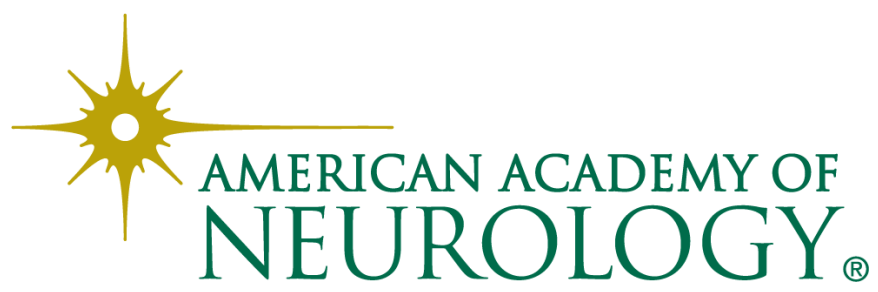

